\title{
Family policies, norms about gender roles and fertility decisions in France and Germany
}

\author{
Clémentine Rossier, Sara Brachet and Anne Salles*
}

\begin{abstract}
Cross-country comparisons show that family policies supporting the work-family combination are related to higher fertility in industrialised countries. We argue that within each country, there is a dominant norm about the care of small children, linked to the shape of family policy, that influences individuals' fertility decisions whatever their gender roles attitudes and practices. We compare western Germany and France, which have different family policy and child care contexts, and also different fertility levels, but exhibit similar attitudes and practices towards gender roles as measured in surveys. Using qualitative data (62 interviews), we show that in each national sample, most individuals manage to agree with the national norm about child care, on top of their varying attitudes towards, and practices of, gender roles. These national norms about child care shape fertility decisions, independently of the provision of child care. In western Germany, where mothers are seen as the best child care providers, women who want or need to work prefer to forgo having children rather than using other possible sources of child care. In France, where child care is seen as best when shared, individuals find child care solutions allowing women to work, even in cases where no institutional care is available.
\end{abstract}

\section{Introduction}

Gender inequities have been linked to low fertility in industrialised nations through two main mechanisms: the absence of institutions facilitating women's combination of work and family on the one hand, and an unequal division of tasks between men and women within households on the other hand. At the macro level, a number of scholars see the absence of governmental policies helping

\footnotetext{
* Clémentine Rossier (correspondence author), Institut National d'Etudes Démographique, Paris, France. Email: clementine.rossier@ined.fr

Sara Brachet, Institut National d'Etudes Démographique, Paris, France.

Anne Salles, Université Paris - Sorbonne (Paris 4), France.
} 
women reconcile paid work and family life as the key factor explaining very low fertility in industrialised countries (Chesnais 1996; McDonald 2000a, 2000b). Consistent with McDonald's theory, empirical studies have shown, at the aggregate level, a positive correlation between female labour force participation, family policies favourable to a work-family combination and fertility trends since the 1980s across industrialised nations (Rindfuss and Brewster 1996; Brewster and Rindfuss 2000; Rindfuss et al. 2003; Engelhardt et al. 2004; Engelhardt and Prskawetz 2004; Adsera 2004).

Gender inequality has also been related to fertility through a micro-level mechanism. A number of studies have shown that men's participation in family work has an impact on couples' fertility intentions and outcomes. Using a representative sample of dual-earner families in the United States, Torr and Short (2004) find a U-shaped relationship between the share of domestic tasks and the probability of having a second child. Other studies have found the same or a positive relationship in other industrialised countries with relatively high fertility levels (Berinde 1999; Duvander and Andersson 2006), as well as in countries with relatively low fertility levels (Olah 2003; Cooke 2004; Cooke 2006; Mills et al. 2008).

Studies seeking to link these two mechanisms together (lack of policies supporting working mothers, unequal division of tasks within households) are rarer. In a seminal paper, De Laat and Sevilla Sanz (2006) suggest that "social externalities" (i.e. shared expectations about gender roles) play a key role in linking the two levels of gender equity. These authors contrast the southern countries of Europe (and Japan) to northern Europe, i.e. the Nordic and AngloSaxon countries; Austria and western Germany fall in between those extremes. These authors argue that in the northern European countries, increasing female labour force participation in the 1970s was followed by more male participation in household work because male participation had become a shared reference. The example set by some pioneering men helped other men participate in housework; with the diffusion of those men's behaviour and their participation in household work (and affordable child care options), couples in these countries were able to have a relatively large number of children in spite of women's labour force participation. In the lowest-low fertility countries, the story was different; conservative gender norms remained the shared reference and prevented men to take up household work, because they increase "the penalty faced by men for engaging in traditionally female domestic activities" (Sevilla Sanz 2010, p. 227); women's labour force participation and fertility were impeded both by the lack of help of their partner and by the lack of affordable child care options.

The effect of norms about gender roles is difficult to disentangle from the structural effect of family policies in cross-country comparisons. Indeed, if Italian women renounce on having children more often than Swedish women, it is both because dominant norms prevented their partner from investing in family work and because of a lack of child care options. The comparison between high-fertility 
France and low-fertility western Germany does not escape this limitation. A qualitative approach helps us overcome this difficulty, however, by giving us detailed information on the availability and desirability of different child care options at the time of fertility decisions. Moreover, the comparison between France and western Germany offers the unique opportunity to disentangle the effect on fertility of norms about gender roles in general (how much men and women should invest in the work and family spheres) from the effect of normative models about child care, likely to be directly shaped by national family policies. Indeed, while individuals have rather similar attitudes towards, and practices of, gender roles in France and Germany as measured in surveys, these countries' policies have been very different until recently, and so are the models of child care acting in each case as a national reference (Fagnini 2002; Salles et al. 2010).

\section{France and Germany}

With a total fertility rate (TFR) of 2.02 children per woman in 2008, France has one of the highest fertility rates in Europe, while Germany, where women had only 1.38 children on average in the same year, has one of the lowest ones. The mean age at birth has increased in both countries during the last few decades and is in fact comparable in Germany (30.0 years in 2008) and in France (29.9 in 2008). The very low level of fertility in western Germany seems to be due to atypically high levels of childlessness compared to the rest of Europe (Dorbritz et al. 2005; Dorbritz 2005): indeed, 22,4\% of the cohort of women born between 1964 and 1968 in western Germany are expected to remain childless, with an even larger proportion remaining childless among highly educated women (Statistisches Bundesamt 2009). The high level of childlessness is the consequence of a 'polarisation' of reproduction in that country (Huinink 2002): "the family-forming-age population can be roughly sub-divided into two groups: those who live with children, and are usually married; and those who have chosen not to have children, the vast majority of whom do not marry" (Dorbritz 2008, p.560). Childlessness is more pronounced among couples with better professional positions and higher educational attainments. Because of a stronger connection between marriage and births in western Germany compared to France, the share of births outside marriage, which has increased in both countries, is still lower there (32.1\% in 2009) than in France (52.6 \% in 20099) (OECD 2011. Arguably owing to the lasting high level of childlessness (Testa and Grilli 2006), Germany is one of the countries in Europe where the desired number of children has fallen. According to the Generations and Gender Survey conducted in 2005 in both countries, respondents intended to have on average 1.7 children in Germany, 
compared to 2.3 children in France. ${ }^{1}$ Note that in both countries immigration does not significantly affect the total fertility level, since migrants tend to adopt the fertility behaviour prevalent in their host country (Toulemon 2006; Milewski 2007).

Both countries invest heavily in family support: in France this support is associated with a longstanding pro-birth political priority and its policies support working mothers (Toulemon et al. 2008). The employment of French mothers is facilitated by child care policies targeting children from early childhood on: in $2005,43 \%$ of children under three years had the benefit of public child care (DREES 2007). From the age of three the public nursery school system guarantees a place for almost every child. On the other hand, Germany prefers to offer a financial support to families with children based on the traditional family model (Le Goff 2002; Salles 2006). Western German family policy, until quite recently, did not finance collective child care, obliging most mothers to stop working at the birth of a child, and then later to work shorter hours (Fagnani 1992; Périvier 2004; Salles 2006). In western Germany in 2009, public child care covered only $5.1 \%$ of children under three years of age (i.e. children having at least seven hours of care per day) (Statistisches Bundesamt 2009). Therefore, although employment rates of women are generally higher in Germany than in France all ages taken together, ${ }^{2}$ mothers, and especially mothers of small children are less often employed in western Germany, and less often full time. Western German mothers with children of preschool age are gainfully employed only for nine hours a week, while French mother spend 22 hours on paid work on average (EFILWC 2007).

Men seem to exhibit similar patterns of parental and household tasks sharing with their partners in both countries, when all ages are taken together (differences are greater when couples with small children are examined). A French time use survey conducted in 1998 shows that women do $69 \%$ of all household tasks (Méda et al. 2004). In Germany, women accomplish $63 \%$ of household tasks according to a study in 2003 (Statistisches Bundesamt 2003). Altogether, given men's involvement in family work in both France and Germany, women's total working hours is only slightly greater than that of men: 62 hours a week in France (57 hours among fathers) and 64 hours for mothers in western Germany (62 hours among fathers). In comparison, women in Mediterranean countries spend about 75 hours a week on paid and unpaid work (EFILWC 2007).

Results of the Generations and Gender Survey 2005 for men and women between 20 and 39 . Kinderwünsche in Deutschland, BiB-Mitteilungen 2/2007, p.19-21. We found the same results for Germany in the Population Policy Acceptance Study of 2003 (Dorbritz et al. 2005, Höhn et al. 2006). The French results were calculated by Arnaud Régnier-Loilier (INED).

2 In $2009,66.2 \%$ of German women aged 15 to 64 were employed, against $60.1 \%$ in France. (Eurostat, communiqué de presse, 117/2010, 04.08.2010 http://epp.eurostat.ec.europa.eu/:) Note that women on parental leave are counted in employment statistics in both countries. 
Western Germany and France are also similar when it comes to individual attitudes towards gender roles (Kalmijn 2003). When compared to the rest of Europe, both countries rank higher than southern and eastern European countries, where individuals have on average more conservative visions of gender roles, and rank lower than northern European and Anglo-Saxon countries. For example, Lück (2005), using International Social Survey Programme data from 2002 found that the acceptance of the male-breadwinner model was similar in the two countries: ${ }^{3} 19 \%$ in France and 20\% in Germany. Northern European countries all had lower scores (between 11 and 18\%), while southern countries had levels over $30 \%$; in eastern European countries even more than $50 \%$ of the respondents supported this model.

\section{Theory and objective}

Social norms are shared modes of regulation, linked to local forms of social recognition (Dubois 2002). They can be formal (written in laws) or informal (e.g. rules of politeness). Social norms are more than 'shared rules', because they refer to underlying values: norms indicate what is desirable, not only what should be done. Norms are also more than 'representations', because they are prescriptive: sanctions penalise those who do not follow them (legal punishments and/or social exclusion).

Norms are plural: several norms often coexist for the same sphere of human activity, in any society. The more or less peaceful co-existence of several norms originates in the superposition of several sources of legitimisation (Chauveau et al. 2001). Norms endorsed by the highest source of authority (for example the State or the most influent social group) are 'dominant'. Dominant norms are shared (to different extents) by most individuals in a society. Some individuals may not subscribe to a dominant norm (for example: criminals in gangs), but they know that most other people agree with the norm in question, and that they will encounter sanctions (punishment, widespread disapproval) if they openly transgress it.

Some norms are adopted by subgroups of individuals with common interests or visions. For example, individuals with a lower social status tend to adopt conservative attitudes towards gender roles, because they help them balance a disempowered experience of the world: women with narrow perspectives on the job market find it rewarding, in the realm of their family, to be the person in charge of children's education and domestic affairs, while men with lower positions on the job market enjoy the higher status they gain in their family by adopting the male-breadwinner role (Luker 1984).

Asked to women between 20 and 50, the question was: "Do you agree or disagree? ... A husband's job is to earn money; a wife's job is to look after the home and family." 
Although many norms are common to entire cultural areas (Reher 1998), national norms also exist, since the State and its laws are an important source of normative legitimisation. Norms about gender roles endorsed and supported by new national family policies are likely to gain weight at the national level because of two mechanisms: these policies shape the actual division of tasks in many households (encouraging men to get involved in family work), and provide normative support to men and women already engaging in the 'policy-approved' behaviour. ${ }^{4}$ At the same time, the shape of family policy in a specific country depends on the relative forces of the groups supporting different normative visions. For both these reasons, cross-country studies usually find individual attitudes towards gender roles to be linked to the shape of family policies (Sjöberg 2004; Adler and Brayfield 2006; Almqvist 2007; Kangas and Rostgaard 2007; Motiejunaite and Kravchenko 2008).

Researchers observe norms, their diversity and distribution, through the normative judgments expressed in individual discourses (Chauveau et al. 2001). Individuals have been found to be more likely to act on norms and to express normative judgments in situations of evaluation, such as in interviews (Dubois 2002). It is possible, in qualitative interviews, to observe dominant norms especially through the discourses of persons with contradicting practices and beliefs. Indeed, these individuals usually mentionthe dominant norm explicitly and downplay the contradictions between their position and the norm, while conformist individuals often do not refer to the norms they see as natural and on which they act. This tendency to downplay one's distance to the dominant norms is known as the 'social desirability' effect in interviews, well known among social science researchers.

In France and western Germany, several norms co-exist regarding the extent to which men and women should be devoting themselves to the professional and to the family spheres, respectively. These two middle European countries have the same mix of individuals with conservative and progressive attitudes and practices towards gender roles, with most individuals in fact having somewhat progressive visions and practices. However, these two countries, until recently, had widely different family policies: a policy encouraging working mothers in France and one encouraging stay-at-home mothers in western Germany. In this article, we ask how individuals navigate this plurality of norms, and whether nationally shared norms about child care, shaped by family policies, have an impact on fertility decisions, independently of the provision of child care services in each country and of individuals' gender role attitudes and practices.

$4 \quad$ As Purr et al. explains it concisely: "The gender system is a social construction that will change only through long-term persistent accumulation of everyday challenges to it. Men who increase their participation in family tasks to approach the share of women challenge both the male and the female identities as defined by the gender system in a society. Such aspirations will be influenced then by the support, or lack of it, men receive from their immediate family members and the community" (2008, p. 1886-1887). 


\section{Methods}

To study the relationship between child care models, gender roles beliefs and practices and individuals' fertility decisions, we adopted a comparative qualitative approach. Qualitative data are well suited to study the interrelations between normative contexts and individuals' beliefs and practices; a cross-country comparison is indicated when reference norms are likely to be shaped by national policies.

Given our interest in family formation, we selected men and women who were about the average age of first childbearing in each country: respondents were all between 28 and 33 years of age, except one male respondent in the German sample who was 37. About one-half of the sample in France and about two-thirds in the German sample were childless; those with offspring often had one child, more rarely two (but more often two in the French sample).

The respondents were selected in Lübeck (western Germany) and Poitiers (France), two cities of comparable size (around 200000 inhabitants). Both towns are located fairly close to a major urban area (Paris in the case of Poitiers, Hamburg in that of Lübeck). Selected individuals had spent their secondary school years in those towns and had not moved further than the nearest major city. Initial lists of possible respondents were built up from school listings or alumni websites, then the snowball technique was applied. The purpose of the study was to investigate social network effects on fertility intentions in a comparative perspective: this mode of selection was meant to control for primary socialisation (Bernardi et al. 2007). The French sample ended up being more diverse. Indeed, young people growing up on small cities tend to move to large cities, especially the more educated and less conformist individuals among them. In the case of Poitiers, most people from the targeted school cohort who did move away went to nearby Paris (where nearly half of the respondents were interviewed). On the other hand, the main cities of emigration from Lübeck lie in southern Germany. Since the research team did not go further than Hamburg to find members of the targeted school cohort (where few of them did emigrate), most respondents in the German sample were interviewed in Lübeck.).

The samples are made of mainly middle-class individuals who have decided to stay close to their hometown after completing their education. They contain enough diversity in terms of gender roles attitudes and practices to study the interrelation between the latter, and norms about child care and fertility decisions in each country.

Interviews were conducted by a doctoral student in Germany and by a postdoctoral fellow in France (second author). Interviews were conducted in private (at the respondent's home or in a quiet public space). Respondents were asked for an individual interview; in rare cases the partner took part in the interview as well. Interviews were recorded and then typed up; the transcripts were not translated. All names have been changed. The study was presented to respondents as a study 
on family formation. We used a problem-centred approach. The interview started with an open-ended question ("Tell me what happened in your life since the end of high school") and subsequently focused on a number of themes (with a series of open-ended questions): having children, gender roles, child care options, having children in one's social network. Respondents were asked to elaborate on their practices and representations on each of these topics. The interviews were supplemented by a short socio-demographic questionnaire.

In a first pre-analytical step, the team of analysts was divided into two (first and second author for the French interviews, third author and an intern for the German ones). Using the NVivo software, the team constructed a common coding scheme; each interview was coded by a pair of analysts. Differences in coding were discussed by the entire team, and the coding scheme was adapted until no further changes were necessary. When teams started to code identically, the remaining interviews were split between the two analysts and coded. In a second step, the group conducted a thematic content analysis. Each interview was summarised on three themes: gender relations, child care arrangements and social networks. Each interview was summarised independently by the same teams of two, and differences in interpretation were discussed during weekly meetings; a final consensual summary was written for each interview. In a third analytical step, the second and third author separately conducted a descriptive analysis of gender roles attitudes and practices in the French and German samples. They each constructed a typology of gender roles for respondents in stable relationships; further exchanges allowed for the creation of a common typology, which included four types: 1) traditional couples, 2) dual-burden couples, 3) egalitarian couples with a focus on the family, 4) egalitarian couples without a focus on the family (Brachet et al. 2010). In both samples, the majority of respondents fell into the two middle categories.

In a final explanatory analytical step, whose results are presented here, the first author looked for national family models and their articulation with gender roles by searching for commonalities in the French sample across gender roles types, and contrasting them against such commonalities in the German sample; all interviews were used at this stage (see description of the 35 German and 27 French respondents in the Appendix). A progressive norm about child care was found to be widely shared in France and a conservative one in Germany, whatever the respondents' attitudes towards and practices of gender roles. To investigate the effect of these national norms on fertility decisions, we then singled out respondents who reacted to the contradicting demands of (women's) investments in the non-family and family spheres by lowering their fertility intentions (10 respondents in the German sample and one in the French sample). We contrasted them to respondents who managed to conciliate work and family, that is respondents who were (or planned to be) dual-earner couples (full time or near full time work for both partners) with (plans of) two children or more (one respondent in the German sample, 13 respondents in the French sample). To 
disentangle the effect of norms about child care from the actual provision of child care, we analysed how these two categories of respondents with contrasting fertility decisions related to and used non-publically funded child care options (father's involvement, private baby sitters, grandparents, other relations).

\section{Results}

\subsection{The national child care model in France}

In the French sample, many mothers of young children work, and quite a few work full time or close to full time. Most childless respondents plan that both partners will continue working (full time or close to full time) after the arrival of a baby. All the women in the sample value their involvement in the job market, and many see time spent at home (after maternity leave) as useless. Sandrine's view regarding homemaking is very common in the French sample (female, 30, cohabiting, one child, accountant).

For my own sake I needed to work. Financially it makes a difference too, but it's true it's mainly my choice. [...] Already by the end of three months [of maternity leave] ... I just had to go out. I'm not made for staying at home.

In case the mother works, many French couples with children have found an arrangement based on the father's participation. For example, Marie's (female, 29, cohabiting, 1 child, policewoman) partner covers the child care hours in the morning and in the evening. Sammy (male, 33, cohabiting, 2 children, computer manager) picks up his children every day from the child-minder, since his wife's work ends only at $8 \mathrm{p} . \mathrm{m}$. These couples experience, to different degrees, shared parenthood, in the sense that both partners are involved in daily child care tasks (feeding, dressing, cleaning, getting up at night, bringing to or fetching from day care etc.). Concomitantly, these respondents hold progressive attitudes towards gender roles, and display few role specialisation beliefs.

I think that there is nothing that... What could I do alone with the children that Nico has never done? No, I see absolutely nothing. Because whether it is cooking, painting, some plasticine, or reading a story before they go to bed or having the bath, or working in the garden... all these things that I do, he does, too. (Camille, female, 29, married, two children, teacher)

The father's participation is viewed as normal by these respondents. Benoît says for example:

Childrearing is the business of both of us. The child, anyway, is made by both of us. (Benoit, male, 27, non-cohabiting, childless, actor) 
Hélène goes as far as not wanting to breastfeed her child, to avoid the exclusion of the father:

I don't think I would breast-feed (...) because during two or three months, the father has a secondary role. [...] As soon as possible, [...] it is really necessary to make a three-way relationship. (Hélène, female, 30, single, childless, psychiatric nurse)

An important share of French respondents is less progressive regarding gender roles. But interestingly, even those French respondents who hold a traditional vision of gender roles all mention also the advantages of working mothers for children, the positive aspects of formal child care and/or underline the necessity for men to participate in family life. By adding some 'progressive' touches to their vision, they manage to keep a traditional outlook at the division of tasks while avoiding being at odds with the 'reference' progressive vision. For example, Ariane has a traditional vision of gender roles.

I will appear 'cliche' once again, but the father, he represents more financial security, and the mother's more into providing affective, maternal security. (Ariane female, 30, single, childless, customer manager)

However, she stresses at the same time that a working mother is a good thing for a child.

To have a working mother also helps to cut the umbilical cord between the mother and the child and to let him grow up, be independent.

Similarly, Elise is ready to slow down her professional activity the day she and her partner decide to have a child. Gender equality does not seem very important to her. She imagines a family where the mother's and the father's roles are clearly differentiated: the father represents authority and the mother affection and care. She explains that this specialisation is natural, because "there are some tasks that men are not able to do". However, Elise would not like to stop working totally; neither would she accept doing all the housework and parenting.

To be able to achieve a distribution of $2 / 3-1 / 3$, that would fit me. I would not like that one of us does not do anything [in terms of domestic and parental work], but that he should do a little bit less than me, that's acceptable. (Elise, female, 28, non-cohabiting, childless, white-collar worker in clinical research)

As underlined here, the planned division of tasks is presented as only slightly different from an equal sharing. Another example is striking. Anne-Sophie makes no egalitarian demands and does not set a high value on equality between men and women. She accepts that parental and domestic tasks will not be shared in her family. 
When they were very small, you couldn't say Marc really took care of them. Who got up in the night? Me. Who gave the bottle? Me. And I was the one who gave them their baths. I must admit, he's not very housework. (AnneSophie, female, 28, cohabiting, 2 children, child-minder currently on parental leave)

However, Anne-Sophie underlines that her partner plays an important emotional or affective role for their children, describing here a common form of 'new fatherhood' which is compatible with a traditional division of parental tasks. For our argument, it is important to note that Anne-Sophie talks about her partner's emotional relation to their children using vocabulary implying that he is involved in actual child care tasks (see terms underlined in the citation below), which is not the case.

Yes, the girls wait for their father to come home in the evening, they jump into his arms. He takes care of them. He's a real mother hen.

It is also important to underline that despite the fact that all respondents in the French sample value women's employed work, working mothers and father's involvement in family tasks, in practice the men remain the main breadwinners in most couples, they have usually better socio-economic positions than their female partners and often perform less domestic and parental tasks; for example, they may practice equal parenting when present, but they are more often absent for professional reasons.

\subsection{The national child care model in western Germany}

In Germany, women usually stop working at the birth of a child. All respondents in the German sample, whatever their visions and practices in terms of gender roles, think a mother should take at least one year of parental leave. Only one woman is thinking about going back to work directly after maternity leave, but she refers to this course of action as one option out of two; she would in fact prefer to take a one-year parental leave. Whether they prefer a long (several years) or short (one year) parental leave, all German respondents think that it should be followed by part-time work for the mother (usually a few hours a week) and subsequently, in some cases, by her full-time employment once the children are older.

Most mothers in the German sample who are not on parental leave work parttime, with working hours chosen so as to encroach as little as possible on time spent with the family, for example during school or kindergarten hours. Bärbel (female, 31, married, 2 children, naturopath in training) for example, is doing a distance training course and works in the evenings, when the children are in bed. These women are often employed for relatively few hours (between five and 16 hours a week in our sample), devoting the rest of the week to domestic and parental tasks. 
Caring for a child is seen as a task that a mother can and should do. Women's family work is highly valued. Most respondents are against the idea of the father taking the parental leave, even if the mother has a better occupational status and earns more than her partner. Asked about the possibility of her husband taking parental leave, Paula says for example:

At the beginning he found it hard to accept that I earn more than him. (...) He still hasn't completely accepted it. So I think there's no question of that [her husband taking the parental leave] for us. He could just as well breast feed the baby! (Paula, 31, in couple, childless, administrative clerk)

The idea that somebody other than the mother could take the parental leave never even crossed some respondents' minds. This division of tasks is often justified by biological arguments: women are not like men; they have a specific role to play in respect to the child. A baby "has instincts" and that is why the mother is "required in the first place" (Stephan, 31, living apart together, childless, student). Certain women point to pregnancy and breast-feeding in order to justify the fact that mothers and not fathers go on parental leave.

Only one respondent does not support the idea that mothers play a special role in childrearing: Jürgen confirms that he is willing to take a parental leave if his wife has a higher salary than himself. His own mother worked while he was a child, and he has not suffered from that situation.

Both parents were working. That means, I very soon became independent, had my own key, was a so-called 'latchkey child'. But I got everything I wanted. (Jürgen, male, 31, single, childless, security advisor)

Most respondents think women should go back to work after parental leave. This wish is motivated partly by financial considerations. However, all women also mention a genuine interest in their jobs; they say they do not want to lose their grip on work (i.e. they do not want to be left behind) and express a desire to stay in contact with their colleagues. Nevertheless, family comes before work, and even the most highly qualified women who have or want a family have clearly given up the idea of a career in our sample. Also, all respondents think that mothers should work part time, because mothers should be there for their children.

I really want to see my child grow up, at least until he goes to school. Even after [he goes to school], you also have to reinforce this link. [...] Maybe Mummy isn't there two afternoons per week, but the rest of the time she is there. And I think this is important, for me too, this is very important. (Nina, female, 30, cohabiting, childless, student)

Interestingly, in our sample, even those women who display more progressive attitudes towards gender roles (i.e. they want to invest themselves more in the employment sphere and think that domestic and parental work should be shared 
by the partners) say, like the rest of all respondents, that child care is best performed by mothers. Franziska is the only German respondent who shared the parental leave with her husband. After 18 months of parental leave, she went back to full-time work while her husband took over at home, enjoying the second 18 months of parental leave. The mother returned to full-time work (which is really unusual in the German sample) because her status as a trainee teacher did not allow her to work part-time. This couple is characterised by progressive attitudes towards gender roles. Franziska comments on her step-parents' reaction to their arrangement in the following terms:

Olaf['s parents thought that he] would work of course, especially because he is more qualified than me, because I am only a teacher and he can earn much more money than me. [...]But nobody said that I could not work. [...] They pitied Olaf a lot, because he had to endure all this baby crying [..](laughs) [...] But Olaf is not like that. (Franziska, female, 29, married, one child, teacher)

However, Franziska regrets that her husband shared the parental leave and she stresses that she will not let him do so for the second child. She has two main reasons for this: she wants to take advantage of it herself, and she noticed that her husband was always irritated in the evening after spending the day with their son. She concludes:

It's all very well for men to want to take the parental leave, but I don't think they have same capacity to stay as unruffled as women.

In this mind set, child care is essentially seen as assumed by mothers, at least in our respondents' comments (both men and women). For example, Paula says that she will bear "the essential responsibility [of child care] for at least eighteen years". Mirroring these statements about the role of mothers, German respondents express traditional visions when it comes to men: they mainly expect men to work full-time to sustain the family. This pattern of full-time work for men and top-up wages for women is illustrated by a comment from Martin:

In the end [the man] must be able to maintain his family while the woman must [be able to] make a decisive contribution to it. (Martin, male, 29, noncohabiting (engaged), childless, technical sales representatives)

This general discourse prevails, although all German respondents say men to be involved to some degree in family work and child care. Respondents were asked to quantify the share of (parental and domestic) work done by each partner, and men participate usually for about $30 \%$ of both these tasks. A majority of those interviewed want the father to be present and to spend some time with their children, even if he does not necessarily have to take care of them during the week. 
I couldn't see myself with a careerist who was theoretically the father of our child, who might bring home a lot of money but would not be there emotionally for the family. (Wiebke, female, 29, non-cohabiting, childless, veterinarian assistant)

\subsection{National child care models and fertility decisions}

To understand how the reference vision about child care shape individuals' fertility decisions in each country, we contrast two groups who answered differently to the contradicting demands placed on them by (women's) desire to invest in both the professional sphere and family formation. Some respondents renounced on having (more) children, faced with these contradicting demands, and almost all of them were in the German sample. Other respondents managed to meet both demands at the same time, i.e. to have two or more children while the mothers kept working (close to) full time, and those were almost all in the French sample. These fertility decisions and outcomes were mainly related to the availability or the absence of publically funded child care, since most of these French respondents use such public child care. However, there are also other child care options (father's involvement, flexibility of work hours, private nannies, help of grandparents and other relations). We will examine here how the two categories of respondents rely to and use these other sources of child care.

\section{Couples with mothers working (almost) full time and (planning) two children or more}

The 'success' stories in the realm of family/work reconciliation are almost all found in the French sample (13 respondents in the French sample, one respondent in the German sample). Among the 13 French respondents who do (or plan to) successfully reconcile the woman's work and family, 11 rely on publically funded child care (collective child care or subsidised child-minders). However, only three of those respondents are coping only with publically funded child care, as in most cases the father and/or the grandparents help a great deal. We already underlined that in France fathers usually help with child care in dual-earner couples. But in most cases, other child care options are also used, as is clear in the following example. Damien is a fireman and works in another town; when on duty, he is absent for entire weeks; his wife has no flexibility in her own work hours and starts sometimes early in the morning. He explains how children are taken care of when both parents are absent in the morning

We have friends, and our parents.. it is a bit like, the one who is the first to say he can help... In fact, if our parents are not available, we ask a friend. For a while, we had a student who came to take care of them in the morning. [..] It is a bit complicated. (Damien, male, 30, married two children, fireman) 
Two French women managed to have children while continuing to work close to full time, and this even without publically funded child care. In both cases, the couples looked for a place in a crèche but did not find one. Camille (29, married, two children, teacher) found no formal child care option in the isolated village she and her family were residing in; Sofia (cohabiting, one child, temporary part-time work in an association) is residing in a large city where places in crèches are very difficult to obtain, and her experience with subsidised nannies was rather unsatisfactory. Camille's first child was taken care for, during its first year, by Camille's mother (two days and a half per week), herself (she did not work on Wednesdays), the father (one day and a half per week), and the arrangements were similar in the following years. In Sofia's case, the couple had the following organisation when their child was small: the father would care for it until 2 p.m. (when he started working), and Sofia and a colleague would then look after the child while working (by phone) at her home.

\section{Couples where the women (want to) work and who forgo having children}

'Failures' to combine women's work with large families (having two children or more) are almost all to be found in the German sample (ten respondents in the German sample and one in the French sample). In nine of these cases, the renouncement is clearly linked to the wish that women remain highly involved in the non-family sphere, while men want to stay strongly committed in their profession as well, or do not want to invest more in the family sphere. For example, Ozan (male, 28, married, one child, technical sales representatives) has already given up a training course to mind their child in the evenings while his Turkish wife attends German classes. Having a second child seems incompatible with the wife wanting to enter the job market. The wife of Markus (male, 28, married, one child, bank clerk) works part-time as a nurse to increase their income as the couple is buying a house. He already looks after his son two weekends a month, but he does not want to have another child, since he pursues a training programme after work and has career ambitions.

Among those respondents, two experienced some form of non-parental child care: both Britta (29, married, one child, at home, physiotherapist in training course) and Markus had grandparents help with one day of child care per week. Despite these forms of support, both couples do not consider having more children. These respondents do not mention father's part-time work, paid private child care, collective private child care child, flexible work hours, grandparents, or a combination of all of the above as a way to allow women to be substantially involved into the labour force while having (more) children. This lack of consideration for non-motherly child care is especially clear in the case of childless German couples who do not want children. For example, Maike thinks children should be taken care of solely by their mothers. She says:

Well, if I wanted to have a child, I would want to have it 100\%, and I am not ready for that. (Maike, 31, in couple, childless, student) 
She renounces on having children without even considering child care options other than herself. Similarly, Nadia thinks that it is out of the question for her to have a child if she is not able to look after it and must entrust it to the care of other people.

I must sincerely say, if both of us work full time, now somehow we have one child or two and they must all the time go to somebody else, well, I wouldn't want that. In that case, I'd rather say I don't want any children at all. (31, Nadia, living apart together, childless, white-collar worker)

Arno (male, 30, living apart together, childless, journalist) fears that for financial reasons, his future wife could not be a stay-at-home mother and thinks about forgoing having children altogether because of that.

The case of Claudia (33, married, childless, student) is especially interesting, because it parallels that of Camille in France. In both cases, both partners are (or will be) teachers and could share all the parental work between them (Claudia explains that one of the two could teach in the morning and the other in the afternoon). But Claudia is not sure she wants a child. She is afraid it would restrict her freedom. In particular she thinks caring for a child on parental leave would be "very stressful and boring" and cannot imagine stopping work, even for a short period. Camille, on the other hand, does not see child care as a particularly demanding task and had two children almost without relying on publically funded child care.

\section{Discussion}

In both the French and the western German samples, we found that most women value their work and are involved in the labour market. What differs between the two countries is their participation in the labour market after the birth of a child, which depends on available child care options and attitudes towards child care. In France, full-time child care for children under the age of three in day care centres or by child-minders is widely accepted and used; a non-negligible share of women works full-time while their children are small. In western Germany, most women feel that they have to stop working at the birth of a child, and that they can take up work again only gradually, often in very part-time positions when the children are small. In the French like in the western German sample, men's role as fathers is valued by all. In both samples, men often assume a non-negligible share of the domestic and parental work, although they usually do less such work than women, especially when women stay at home (especially when the children are small in the German sample).

In both countries, one finds respondents holding a more traditional vision of gender roles as well as more progressive respondents, and practices vary from traditional to equitable. Whatever their general opinions and practices regarding 
gender roles, we find that respondents' discourses are strongly coloured by a 'national family model', a progressive golden standard in the case of France, and a traditional one in the case of western Germany. Respondents in France, even those exhibiting traditional visions and practices of gender roles, highlight that a working mother and formal child care also bring some benefits to children. Respondents in western Germany, even the most progressive one, underline that mothers do a better job than fathers (and non-parental child-minders) in caring for children. When it comes to the man's role, western German respondents say that men have to be involved in child rearing on top of being the main breadwinner. In France, respondents do not insist on the economic responsibilities of men and speak mainly of their fatherly role, although they are in fact the main breadwinner in most cases.

In this analysis, we found that individuals try to present their general arrangements and visions in terms of gender roles as being close to the relevant 'national family model', and that most succeed in doing so. The trick is usually done by adding a 'nationally correct' layer on top of one's initial vision, in a way which does not undermine it, or to find a 'good enough excuse' explaining why one does not follow the model. At first glance, the national model of child care seems to be nothing else than an ideological gimmick, with no impact on practices.

However, we find that national norms about child care are linked to individuals' fertility decisions. In the western German sample, individuals faced with the contradictory demands of women's work and family formation forgo one or the other of these demands (the 'polarisation' phenomenon). Individuals are forced into this polarisation because of a lack of subsidised child care options, but also because they think only mothers can take care of small children, when in fact, in some cases, creative child care solutions could be sought. In France, most individuals combine work and family thanks to subsidised child care, but some manage to do so even in the absence of it, because they have a positive outlook on non-motherly child care and actively seek creative child care solutions.

Even if the mix of individual attitudes and practices towards gender roles are similar today in the two samples and according to survey data aggregating all ages, we show that the more positive outlook of French respondents about nonmotherly child care predisposes the latter to adopt more progressive gender role practices when children are small. In France, even conservative individuals are open to working mothers, and such arrangements, when they are adopted, usually entails that men participate in family work. Attitudes and practices towards gender roles can be expected to diverge in France and Germany over the long term, should their family policies stay the same; alternatively, it is possibly that gender roles attitudes and practices would have been more progressive in western Germany than in France, if both countries had adopted a policy supporting the work-family combination at the same moment. 
Our results show in details how "social externalities" (De Laat and Sevilla Sanz 2006; Sevilla Sanz 2010) link the two levels of gender inequality which are relevant for fertility decisions: policies supporting the work-family combination and men's involvement in family work: family policies nurture dominant norms about child care, which encourage (or do not encourage) couples to use nonmotherly sources of child care (and to have children or not). The findings indicate that this mechanism may be especially important for childless individuals: in our data, childless individuals, when they do not want children, refer explicitly to norms (which are impossible to meet) about child care, while parents renouncing on having more children talk more often about the lack of actual child care options. Similarly, Ruckdeschel (2010), using data on attitudes about child care, division of tasks (male-breadwinner/dual-earner families) and fertility intentions from the GGP surveys in France and Germany found that 'cultural factors' (attitudes towards child care) were linked to fertility decisions of individuals with no children, while 'structural factors' (whether the mother was working or not) had an impact on the fertility decisions of parents in Germany.

Because a widespread national norm about child care is like an 'open window' or a 'footnote' added to all individual belief systems, current measures of individual gender role attitudes in quantitative surveys may have some difficulties picking up on this dimension. For example, according to the GGP surveys, $44 \%$ of childless respondents agree with the statement, "A pre-school child is likely to suffer if his/her mother works" in western Germany, while 39\% of respondents say so in France (Ruckdeschel 2010): our results suggest much larger differences. Other questions may be more successful in picking up on the effect of dominant norms ${ }^{5}$,

The Theory of Planned Behaviour (Ajzen 1991) pays attention to the fact that dominant norms are important dimensions of individual decision making: in this model, 'subjective norms' (i.e. individuals' perception of what others wants them to do) enter the decision-making process. This model can be used to pick up on the effect of 'social externalities', 'social influence' or 'dominant norms' on fertility decisions (Rossier and Bernardi 2009).

\footnotetext{
For example: "What would you think of a male friend taking on part-time work to take care of his small child?" "What would you think of a female friend working full time, her small child staying in paid child care from morning until evening?" "Do you think your friends/mother/father/brother and sister/boss/colleagues would disprove if you (your male partner) were to diminish your working time in order to take care of your small child?" "Do you think your friends/mother/father/brother and sister/boss/colleagues would disprove if you (your female partner) were to continue working full-time after the birth of your child and rely on paid child care?"
} 


\section{Conclusion}

Our analysis shows striking differences in the 'national child care model' between France and western Germany: all respondents share, on top of their individual vision of gender roles, a predisposition towards shared care in France and towards motherly care in western Germany. Individuals fit their own position and practices within the nationally dominant vision by underscoring some aspects of their beliefs and not others, or by adding some reservations and precisions to their position. This 'national golden standard' about child care shapes individual fertility decisions (whatever the general attitudes towards gender roles), because it encourages women who want to invest in the non-family sphere to have children even in the absence of formal child care solutions in France, and it discourages such women to have children in western Germany, even when informal child care solutions could be available.

The study of 'social externalities' in demography has certainly been slowed down by the difficulty of pinning down 'dominant norms' with individual survey data. More research is necessary to disentangle, in different policy contexts, individuals' perception of child care, the perception they have of other people's opinion on child care, and how these dimensions are linked to their gender role practices and fertility decisions. Survey questions about others' vision of child care could be one way to proceed.

\section{Acknowledgements}

We thank Laura Bernardi for her interest in and support of qualitative comparisons and her comments on an earlier draft. This comparative analysis has been funded by the European Union's Seventh Framework Programme under grant agreement $n^{\circ} 217173$ (REPRO). We thank the Institut national d'études démographiques for funds for the French data collection, the Institut Emilie du Châtelet for a post-doctoral fellowship in 2007 which supported the collection and preliminary analysis of the French data, the IRG and the MPIDR for funding the German data collection and analysis, Sylvia Keim and Andreas Klärner for their help in accessing and understanding the German data, and Catriona Dutreuilh and Harriet Coleman for English translation and editing. 


\section{References}

Adler, M.A. and A. Brayfield 2006. Gender regimes and cultures of care: public support of maternal employment in Germany and the United States. Marriage and Family Review 39(3-4): 229-253.

Adsera, A. 2004. Changing fertility rates in developed countries. The impact of labor market institutions. Journal of Population Economics 17(1): 17-43.

Almqvist, A.-L. 2007. Expectations relating to childcare among French and Swedish families. Community, Work \& Family 10(1): 17-38.

Ajzen, I. 1991. The Theory of Planned Behavior. Organizational Behavior and Human Decision Processes 50: 179-211.

Berinde, D. 1999. Pathways to a third child in Sweden. European Journal of Population 15: 349-378.

Bernardi, L., S. Keim and H. von der Lippe 2007. Social influences on fertility: a comparative mixed methods study in Eastern and Western Germany. Journal of Mixed Methods Research 1(1): 23-47.

Brachet S., M.-T. Letablier and A. Salles 2010. Devenir parents en France et en Allemagne: Normes, valeurs, représentations. Politiques sociales et familiales 100: 79-92.

Brewster, K.L. and R.R. Rindfuss 2000. Fertility and women's employment in industrialized nations. Annual Review of Sociology 26: 271-296.

Chauveau J.-P., M. Le Pape and J.-P. Olivier de Sardan 2001. La pluralité des normes et leurs dynamiques en Afrique. Implications pour les politiques publiques. In Inégalités et politiques publiques en Afrique : pluralité des normes et jeux d'acteurs, G. Winter, (coord.) with J.-P Chauveau, J. Courade, J. Coussy, M. Le Pape and M. Levy. Paris, 145-162. IRD-Karthala.

Chesnais, J.-C. 1996. Fertility, family, and social policy in contemporary Western Europe. Population and Development Review 22(4): 729-740.

Cooke, L.P. 2004. The gendered division of labor and family outcomes in Germany. Journal of Marriage and Family 66(5): 1246-1259.

Cooke, L.P. 2006. Le Sud Revisité: Équité entre les Sexes et Fécondité en Italie et Espagne. Recherches et Prévisions. Paris: Caisse Nationale d'Allocations Familliales.

De Laat, J. and A. Sevilla Sanz 2006. Working women, men's home time and lowest-low fertility. ISER Working Paper 2006-23. Colchester: University of Essex.

Dorbritz, J., A. Lengerer and K. Ruckdeschel 2005. Einstellungen zu demografischen Trends und zu bevölkerungsrelevanten Politiken. Ergebnisse der PPA Study in Deutschland. Wiesbaden: Bundesinstitut für Bevölkerungsforschung.

Dorbritz, J. 2005. Kinderlosigkeit in Deutschland und Europa: Daten, Trends und Einstellungen. Zeitschrift für Bevölkerungswissenschaft 4: 359-407.

Dorbritz, J. 2008. Germany: family diversity with low actual and desired fertility. Demographic Research 19(17): 557-598.

Dubois, N. 2002. Autour de la norme sociale. Les Cahiers de Psychologie Politique 2. http://lodel.irevues.inist.fr/cahierspsychologiepolitique/index.php?id=1640.

Duvander, A.-Z. and G. Andersson 2006. Gender equality and fertility in Sweden: A study of the impact of the father's uptake of parental leave on continued childbearing. Marriage and Family Review 39(1/2): 121-142. 
DREES Direction de la recherche, des études, de l'évaluation et des statistiques 2007. L'accueil collectif et en crèches familiales des enfants de moins de six ans en 2006. Etudes et résultats 608.

Engelhardt, H., T. Kögel and A. Prskawetz 2004. Fertility and women's employment reconsidered: a macro-level time-series analysis for developed countries: 1960-2000. Population Studies 58(1): 109-120.

Engelhardt, H. and A. Prskawetz 2004. On the changing correlation between fertility and female employment over space and time. European Journal of Population 20(1): $35-62$.

EFILWC European Foundation for the Improvement of Living and Working Conditions 2007. First European quality of life survey: time use and work-life options over the life course.

Fagnani, J. 1992. Travail et fécondité en France et en Allemagne de l'Ouest. Les Françaises font-elles des prouesses? Revue française des affaires sociales 2: 129-148.

Fagnani, J. 2002. Why do French women have more children than German women? Family policies and attitudes towards child care outside home. Community, Work and Family 5(1): 103-120.

Höhn, C., A. Ette and K. Ruckdeschel 2006. Kinderwünsche in Deutschland. Konsequenzen für eine nachhaltige Familienpolitik. Bundesinstitut für Bevölkerungsforschung; Robert Bosch Stiftung.

Huinink, J. 2002. Polarisierung der Familienentwicklung in europäischen Ländern im Vergleich. In Elternschaft heute. Gesellschaftliche Rahmenbedingungen und individuelle Gestaltungsaufgaben, ed. N.F. Schneider and H. Matthias-Bleck, 49-73. Opladen: Leske+Budrich.

Kalmijn, M. 2003 Country differences in sex-role attitudes: cultural and economic explanations. In: The cultural diversity of European Unity, W. Arts, J. Hagenaars and L. Halman. Leiden, Boston: Brill.

Kangas, O. and T. Rostgaard 2007. Preferences or institutions? Work-family life opportunities in seven European countries. Journal of European Social Policy 17(3): 240-256.

Le Goff, J.M. 2002. Cohabiting unions in France and West Germany: transitions to first birth and first marriage. Demographic Research 7(18): 593-624.

Lück, D. 2005. Cross-national comparison of gender role attitudes and their impact on women's life courses. Globalife Working Paper 67.

Luker K. 1984. Abortion and the politics of motherhood. Berkeley: University of California Press.

McDonald, P. 2000a. Gender equity, social institutions and the future of fertility. Journal of Population Research 17(1): 1-16.

McDonald, P. 2000b. Gender equity in theories of fertility transitions. Population and Development Review 26(3): 427-439.

Méda D., G. Cette, N. Dromel 2004. Les pères, entre travail et famille. Les enseignements de quelques enquêtes. Recherches et Prévisions 76: 7-21.

Motiejunaite, A. and Z. Kravchenko 2008. Family policy, employment and gender-role attitudes: a comparative analysis of Russia and Sweden. Journal of European Social Policy 18(1): 38-49.

Milewski, N. 2007. First child of immigrant workers and their descendants in West Germany: interrelation of events, disruption, or adaptation? Demographic Research 17(29): 859-896. 
Mills, M., L. Mencarini, M.L. Tanturri and K. Begall 2008. Gender equity and fertility intentions in Italy and the Netherlands. Demographic Research 18(1): 1-26.

OECD. 2011. OECD Family Database, OECD, Paris. http://www.oecd.org/social/family/ database

Oláh, L. 2003. Gendering fertility: second births in Sweden and Hungary. Population Research and Policy Review 22: 171-200.

Périvier, H. 2004. Emploi des mères et garde des jeunes enfants en Europe. Revue de l'OFCE 90: 224-258.

Purr, A., L.S. Oláh, M.I. Tazi-Preve and J. Dorbritz 2008. Men’s childbearing desires and views of the male role in Europe at the dawn of the 21st century. Demographic Research 19(56): 1883-1912.

Reher, D.S. 1998. Family ties in Western Europe: persistent contrasts. Population and Development Review 24(2): 203-234.

Rindfuss, R.R. and K.L. Brewster 1996. Childrearing and fertility. Population and Development Review 22(Suppl.): 258-289.

Rindfuss, R.R., K.B. Guzzo and S.P. Morgan 2003. The changing institutional context of low fertility. Population Research and Policy Review 22(5-6): 411-438.

Rossier, C. and L. Bernardi 2009. Social interaction effects on fertility: intentions and behaviors. European Journal of Population 25: 467-485.

Ruckdeschel, K. 2010. "Rabenmutter" vs. "Mère Poule". The influence of structural factors and individual value orientations on fertility intentions: Germany in comparison with France. "From intentions to behaviour: reproductive decisionmaking in a macro-micro perspective". 2-3 December 2010, Vienna.

Salles, A. 2006. La politique familiale allemande: les limites de l'action de l'Etat. Critique Internationale 31: 95-117.

Salles, A., C. Rossier and S. Brachet. 2010. Understanding the long term effects of family policies on fertility: the diffusion of different family models in France and Germany. Demographic Research 22(34): 1057-1096.

Sevilla Sanz, A. 2010. Household division of labor and cross-country differences in household formation rates. Journal of Population Economics 23: 225-249.

Sjöberg, O. 2004. The role of family policy institutions in explaining gender-role attitudes: a comparative multi-level analysis of thirteen industrialized countries. Journal of European Social Policy 14(2): 107-123.

Statistisches Bundesamt 2003. Wo bleibt die Zeit, die Zeitvervendung der Bevölkerung in Deutschland 2001-02. Wiesbaden.

Statistisches Bundesamt 2009. Mikrozensus 2008. Neue Daten zur Kinderlosigkeit in Deutschland. Wiesbaden.

Testa, M.R. and L. Grilli 2006. The influence of childbearing regional contexts on ideal family size in Europe. Population 61(1-2): 107-137.

Torr, B.M. and S. Short 2004. Second births and the second shift : a research note on gender equity and fertility. Population and Development Review 30(1): 109-130.

Toulemon, L. 2006. Fertility among immigrant women and men in France: new data, new approach. Paper presented at the Population Association of America 2006 Annual meeting, Los Angeles, California, March 30-April 1, 2006.

Toulemon, L., A. Pailhé and C. Rossier 2008. France: high and stable fertility. Demographic Research 19(16): 503-556. 


\section{Appendix}

\section{Appendix 1: \\ Age, marital status, number of children and occupational status of the western German respondents}

Amelie, 32, single, childless, educator, jobless

Anja, 29, LAT, ${ }^{6}$ childless, senior clerk human resources

Arno, 30, LAT, childless, journalist

Bärbel, 31, married, two children, training course (naturopath)

Britta, 29, married, one child, at home, physiotherapist (in training course)

Christin, 30, in couple, childless, psychologist

Claudia, 33, married, childless, student

Franziska, 29, married, one child, teacher (husband in parental leave)

Inge, 39, married, one child, at home, biologist

Jan, 30, single, childless, call centre agent and student

Jürgen, 31, single, childless, security adviser

Julia, 34, single, childless, dental hygienist

Kathrin, 29, in couple, childless, studied business economics, clerk

Lars, 27, single, childless, dairy expert

Maike, 31, in couple, childless, student

Markus, 28, married, one child, bank clerk (wife in part time)

Martin, 29, LAT (engaged), childless, technical sales representatives

Martina, 30, LAT, childless, restoring furniture

Matthias, 29, married, childless, portfolio manager

Melanie, 33, married, one child, postwoman, part time

Nadia, 31, LAT, childless, white collar worker

Nina, 30, in couple, childless, student

Ozan, 28, married, one child, technical sales representatives (wife at home)

Paul, 31, married, childless, student

Paula, 31, in couple, childless, administrative clerk

Petra, 29, married, one child, at home, insurance agent

Ralf, 28, single, childless, student

Stefan, 31, LAT, childless, student

Susanne, 30, LAT, childless, insurance agent

Thomas, 31, married, childless, white-collar worker

Tilman, 37, married, one child, commercial agent (wife at home)

Tobias, 31, married, two children, employee in a public service (wife at home)

Ulla, 29, in couple, pregnant, manager

Ulrich, 29, single, childless, student

Wiebke, 29, LAT, childless, veterinarian assistant

\footnotetext{
LAT: Living Apart Together is a term for couples who, whilst committed to each other, are living in separate homes.
} 


\section{Appendix 2: \\ Age, marital status, number of children and professional status of the French respondents}

Alice, 27, LAT, childless, translator

Amandine, 28, married, one child, white-collar worker in a pharmaceutical laboratory

Anne-Sophie, 28, cohabiting, two children, on parental leave, no employment

Ariane, 30, single, childless, customer manager

Benoît, 27, LAT, childless, actor

Camille, 29, married, two children, teacher

Damien, 30, married, two children, fireman

David, 30, single, childless, teacher

Dominique, 29, in (homosexual) couple, one child, marketing assistant

Elise, 28, LAT, childless, white collar worker in clinical research

Eric, 32, married, two children, fireman

Etienne, 31, married, two children, commercial worker

Fabien, 28, single, childless, nurse

Franck, 29, single, childless, fiscal agent

Hélène, 30, single, childless, psychiatric nurse

Jérémy, 28, cohabiting, childless, chemist, looking for a job

Justine, 30, LAT, childless, commercial assistant

Karine, 29, cohabiting, childless, customer manager

Marie, 29, cohabiting, one child, policewoman

Patrick, 27, single, childless, student

Sammy 33, cohabiting, two children, computer manager in an association

Sandrine, 30, cohabiting, one child, accountant

Sofia, 29, cohabiting, one child, temporary part-time work in an association

Sylvain, 31, married, three children, joiner

Sylvie, 28, LAT, childless, management assistant

Thierry, 32, married, one child, engineer in an architect's office

Valentine, 28, separated, one child, manager in the building trade 